\title{
A LIBERDADE DE CRENÇA E CULTO, O SACRIFÍCIO DE ANIMAIS E A APLICAÇÃO DA RAZOABILIDADE À LUZ DO JULGAMENTO DO RECURSO EXTRAORDINÁRIO (RE) 494.601/RS
}

http://dx.doi.org/10.21527/2176-6622.2021.55.230-241

Recebido em: 7/9/2020

Aceito em: 18/11/2020

Marcus Geandré Nakano Ramiro

Universidade Cesumar (UniCesumar). Av. Guedner, 1610 - Jardim Aclimação. CEP 87050-390. Maringá/PR, Brasil. http://lattes.cnpq.br/6416806814615848. http://orcid.org/0000-0001-7731-5957. marcus.geandre@gmail.com

\section{RESUMO}

A liberdade religiosa, à luz da Declaração Universal dos Direitos Humanos, foi consagrada na legislação pátria, pela Constituição Federal de 1988, como um direito fundamental, desdobrando-se na liberdade de crença e culto. Essa liberdade corre o risco de ser ameaçada, principalmente quando se trata de religiões minoritárias no país, como no caso daquelas que incluem o sacrifício de animais em suas liturgias. Tal assunto, sempre muito controvertido, encontrou respaldo jurisprudencial ao ser discutido em sede de Corte Constitucional quando se exigiu um apurado debate sobre o assunto e o correto uso dos postulados normativos para sua aplicação, compreensão e concretização, o que se busca analisar no presente artigo como forma de colaborar na evolução das instituições jurídicas e na consolidação da democracia.

Palavras-chave: Direitos fundamentais. Princípios. Liberdade religiosa. Razoabilidade. RE 494601.

$$
\begin{aligned}
& \text { FREEDOM OF BELIEF AND WORSHIP, SACRIFICE OF ANIMALS AND THE APPLICATION OF } \\
& \text { REASONABILITY IN THE LIGHT OF THE JUDGMENT OF EXTRAORDINARY RESOURCE } 494.601 \text { / RS }
\end{aligned}
$$

\section{ABSTRACT}

Religious freedom, in the light of the Universal Declaration of Human Rights, was enshrined in national legislation, by the 1988 Federal Constitution, as a fundamental right, unfolding in freedom of belief and worship. This freedom is in danger of being threatened, especially when it comes to minority religions in the country, as in the case of those that include animal sacrifice in their liturgies. This subject, always very controversial, found support in jurisprudence when it was discussed at the Constitutional Court when an accurate debate was demanded on the subject and the correct use of normative postulates for its application, understanding and concretization, which is sought to be analyzed in this article as a way to collaborate in the evolution of legal institutions and in the consolidation of democracy.

Keywords: Fundamental rights. Principles. Religious freedom. Reasonability. RE 494601.

\section{SUMÁRIO}

1 Introdução. 2 A liberdade religiosa e o sacrifício de animais. 2.1 Liberdade de crença e culto. 2.20 sacrifício de animais em cultos religiosos e o direito à vida animal não humana. 3 Os postulados normativos e o conflito de regras e princípios. $4 \mathrm{~A}$ aplicação da razoabilidade à luz do julgamento do RE 494.601/RS. 4.1 Aspectos materiais do RE 494.601/RS. 4.2 A aplicação do postulado da razoabilidade. 5 Conclusão. 6 Referências. 


\section{INTRODUÇÃO}

O julgamento de temas que reflitam fortemente no Estado Democrático de Direito, principalmente quando chegam à Corte Constitucional, deve sempre gerar no mundo jurídico e acadêmico uma inquietação que conduza o jurista ao aprofundamento e, por que não, à validação, à luz de outros paradigmas, daquilo que se encontra em debate.

Para isso, o presente artigo percorre os fundamentos para a correta compreensão da liberdade religiosa garantida pela Constituição Federal de 1988, demonstrando seu desdobramento na liberdade de crença e culto, diferenciando-as e dando sua extensão e implicações pragmáticas. O culto, ultrapassando o mundo das ideias, exige do fiel meios de exteriorização daquilo em que crê, gerando condutas que, em virtude de sua origem - muitas vezes não majoritária -, geram questionamentos se seriam aceitáveis ou não, sendo necessário investigar os limites desse culto ante a outras garantias advindas do Estado Democrático.

Justamente com foco nestes cultos minoritários no Brasil, vem a questão do sacrifício dos animais, sua imolação dentro dos rituais exigidos por algumas religiões e sua aceitabilidade. Seria lícita a subjugação dos animais para a satisfação das necessidades humanas para além da subsistência, ou já é possível vislumbrar, na legislação, gérmens de uma mudança da visão legislativa antropocêntrica para uma que seja mais biocêntrica?

Para a resposta a tais perguntas, além da vontade política necessária para se empreender tal caminhada, enquanto ela não acontece, há que se valer dos métodos corretos para que a vontade do legislador constituinte seja respeitada e o tempero constitucional garanta a democracia fundante. Por isso o estudo dos postulados normativos e a oportunidade de, unindo assuntos da mais alta relevância principiológica, vê-los em debate de sede constitucional, verifica sua aplicação, colaborando como modelo para outras decisões, conduzindo para a compreensão de que, ao se deixar de respeitar um postulado, não há afronta a ele, mas necessariamente à norma em debate, que poderá deixar de ser corretamente aplicada por falha em seu suporte metodológico.

Desta forma, busca-se unir o conhecimento a assuntos da mais alta relevância no mundo do direito ao estudo dos postulados e sua correta aplicação, acreditando ser oportuno e necessário para o desenvolvimento das instituições jurídicas e sua inerente segurança.

\section{A LIBERDADE RELIGIOSA E O SACRIFÍCIO DE ANIMAIS}

\subsection{Liberdade de crença e culto}

A Constituição Federal de 1988 assegurou, dentre os direitos fundamentais, a liberdade religiosa, desdobrada na liberdade de crença e culto. À luz das atrocidades cometidas na Segunda Guerra Mundial, que culminaram na posterior Declaração Universal dos Direitos Humanos (DUDH), entendeu o legislador constituinte que estaria, dentro das condições básicas de respeito à dignidade e das condições mínimas para o desenvolvimento da personalidade humana, garantir esse direito.

Conforme o artigo XVIII da DUDH, a liberdade religiosa "implica a liberdade de mudar de religião ou de convicção, assim como a liberdade de manifestar a religião ou convicção, sozinho ou em comum, tanto em público como em privado". Assim, nesta esteira, o legislador constituinte consignou no artigo 5, inciso VI, a tutela da liberdade religiosa no Brasil, manifestada por meio da liberdade de crença e culto, representando "inviolável a liberdade de consciência e de crença, sendo assegurado o livre exercício dos cultos religiosos e garantida, na forma da lei, a proteção aos locais de culto e a suas liturgias".

Na liberdade de crença há possibilidade de - na seara religiosa - acreditar-se no que se quiser, ou mesmo não acreditar em nada, sendo problema interno do ser humano, problema de fé, sem necessidade de exteriorização. Já na liberdade de culto, há possibilidade ou necessidade - conforme algumas religiões - de se realizar o culto conforme exigido pela fé e levar essa mesma mensagem de fé cultuada a outras pessoas, sendo, então, o culto, conforme Cretella Júnior (1997, p. 2.018), "a fé exteriorizada". 
Até pouco tempo ainda não se tinha jurisprudência consolidada dos Tribunais Superiores sobre o tema, o que foi suprido por meio do julgamento da Ação Direta de Inconstitucionalidade 4.439 (que se debruçou sobre a constitucionalidade do ensino religioso confessional em escolas públicas, com decisão proferida em 27 de setembro de 2017), bem como o julgamento do Recurso Extraordinário 494.601/RS (tema de estudo do presente artigo), com decisão proferida em 23 de março de 2019.

Sobre a questão da liberdade de crença e culto no Estado laico, os votos dos ministros do Supremo Tribunal Federal parecem finalizar essa discussão em sede de Corte Constitucional, como se apresenta no julgamento deste último:

Todos são livres em direitos e dignidades. Todos são livres para adotar a sua orientação pessoal, pedagógica, sexual, bem como sua indicação ao seu pendor religioso. O parâmetro de controle é exatamente a Constituição na medida em que ela torna inviolável esse direito de praticar-se a religião da forma que melhor se convence. Todos nós temos nossas divindades e acreditamos nos nossos deuses. E, juridicamente, essa é uma questão extremamente simples porque é um direito fundamental, como aqui já foi destacado, que garante a liberdade de crença e, acima de tudo, a liberdade de praticar os seus cultos, e a fortiori esses cultos são acompanhados de liturgias (Voto do Ministro Luiz Fux).

Insisto, um Estado não consagra verdadeiramente a liberdade religiosa sem absoluto respeito aos seus dogmas, suas crenças, liturgias e cultos. $\mathrm{O}$ direito fundamental à liberdade religiosa não exige do Estado concordância ou parceria com uma ou várias religiões; exige, tão somente, respeito; impossibilitando-o de mutilar dogmas religiosos de várias crenças (Voto do Ministro Alexandre de Morais).

Assento, desde o início, que o tema aqui versado cuida de liberdade religiosa. E a liberdade religiosa, tal como a vejo, é um direito fundamental das pessoas; é um direito que está associado às escolhas mais essenciais e mais íntimas que uma pessoa pode fazer na vida, tanto a de professar uma religião como a de não professar nenhuma religião. Mas essa é uma escolha existencial na qual o Estado não deve interferir, salvo para assegurar o exercício adequado desse direito. Devo dizer que sou um antigo e intenso defensor da liberdade religiosa por muitas razões, até, inclusive, pessoais. Mas, mesmo no caso que nós discutimos aqui, do homeschooling, do direito de as famílias educarem seus filhos em casa, adotei uma posição que não prevaleceu de que, em nome da liberdade religiosa, as famílias tinham o direito de fazer essa opção. Eu, pessoalmente, nem acho melhor; acho melhor a escolarização normal, porém, penso que as pessoas, seja qual for o seu credo, têm esse direito de optar por uma educação doméstica religiosa. Apenas enfatizo esse ponto porque, defensor que sou do Estado laico, defendo o direito de as pessoas professarem as suas religiões na intensidade em que optarem por fazer (Voto do Ministro Roberto Barroso).

Ao garantir a liberdade de culto, portanto, quis o legislador constitucional proteger os rituais de cada religião e a possibilidade de fidelidade aos costumes e às tradições inerentes às liturgias, mas conferiu ao legislador infraconstitucional (em consonância com o texto maior) os eventuais direcionamentos e restrições que julgar cabíveis, de modo que a garantia prevista no inciso $\mathrm{Vl}$, do artigo 5o, não se apresenta absoluta, devendo ser sempre interpretada à luz da Constituição como um todo e, ainda, no que couber, aos direcionamentos da legislação infraconstitucional.

O cuidado que se deve ter ao analisar tais questões e limitações não deve, entretanto, envolver aquilo que se acha certo ou errado em sede de religião, mas aquilo que realmente envolva ilicitude clara e objetiva seja nos termos da norma constitucional ou infraconstitucional.

Assim sendo, os locais de culto e as liturgias são protegidos pela Constituição Federal, mas, se dentro do culto, houver afronta a outros direitos também constitucionalmente garantidos, há que se relativizar tal princípio para harmonizá-lo dentro do contexto constitucional e se alcançar o Estado Democrático de Direito querido, ou seja, se dentro de um local de culto estiver acontecendo - por exemplo - um ato criminoso, há que se intervir neste local, mesmo sendo constitucionalmente protegido; se um culto exigir - ainda em sede de exemplo - a realização de ato ilegal, poderá haver restrições a ele, mesmo que o ato seja costumeiro ou tradicionalmente inerente ao culto que se pretende realizar.

\subsection{0 sacrifício de animais em cultos religiosos e o direito à vida animal não humana}

Há, na atualidade, uma forte corrente doutrinária em defesa dos direitos dos animais, apresentando a ascensão de possíveis paradigmas que dispõem como necessário o repensar da superioridade do ser humano dentro do reino animal, que coloca os demais na condição de objetos e lhes nega a titularidade dos direitos à 
vida, à integridade física e à liberdade. Neste novo paradigma, os seres humanos deveriam repensar a necessidade de uma convivência harmônica com todas as demais formas de vida da Terra, de modo particular com os animais não humanos (SILVA, 2007).

Este pensamento busca migrar de um antropocentrismo para um biocentrismo (LEVAl, 2006), quando o ser humano deve assumir o dever de preservar a natureza, respeitando o valor de todos os seres vivos, deixando de explorar o meio ambiente apenas com fins de satisfação de seus interesses, mas harmonizando-se com ele e cuidando da vida em todos os seus aspectos, de modo que o abate desmedido de animais (mesmo para consumo humano), seu uso para fins laborais, culturais ou religiosos, deve ser uma prática aos poucos minorada e, quiçá, ao fim, desaparecida.

Apesar do avanço de tais pensamentos, não se encontra no texto constitucional brasileiro vigente norma que proíba a morte ou o sacrifício de animais, limitando-se o legislador constitucional a vedar, na forma da lei, práticas que coloquem em risco a extinção de espécies ou submetam os aninais à crueldade (cf. artigo 225, $\S 1$, inciso VII c/c §7ㅇ da Constituição Federal), de modo que o que é vedado constitucionalmente é o abate ou a submissão de animais à crueldade, e que, para maior clareza e aplicação, deve ainda ser regulamentado em lei infraconstitucional.

No campo do Direito Internacional há a participação do Brasil como signatário da Declaração Universal dos Direitos dos Animais (1978) sendo, entretanto, uma declaração proclamada em conferências e instâncias desprovidas de personalidade jurídica internacional, trazendo aos Estados signatários simples compromissos políticos de caráter indicativo, mas que expõe, em seu artigo 11, vale ressaltar, que a morte desnecessária de um animal constitui um biocídio, ou seja, um crime contra a vida.

A pergunta que se faz no caso é a abrangência da "necessidade" supramencionada, indagando se a morte de animais não humanos em cultos religiosos se encaixaria nela ou não. Para os defensores dos direitos dos animais, dentro de um contexto de evolução sociológica necessária das religiões, tal prática deveria ser extinta, prescindindo do sacrifício animal a partir de novas interpretações inerentes às reflexões de hoje no campo de tais direitos (LOURENÇO, 2007) e valendo-se, ainda, do caráter não absoluto da liberdade de culto, que vai até onde a lei lhe permitir, quando já não é aceito o sacrifício de seres humanos, por exemplo.

No campo jurisprudencial, tal debate encontrou destaque no julgamento do Recurso Extraordinário 494.601/RS (um dos objetos de análise deste artigo), no qual justamente foi discutida a abrangência da necessidade anteriormente levantada, quando os representantes de várias religiões, que se valem do sacrifício de animais em seus cultos (principalmente as de matriz africana) e que figuraram como amici curiae no processo, se manifestaram indicando o contexto, a necessidade e a sacralidade do sacrifício dos animais em seus cultos, ultrapassando a visão de vida apresentada pelos defensores dos direitos dos animais, quando a sacralização teria um caráter integrativo e de respeito com a natureza, o que não acontece no caso do abate (aos milhões) para consumo humano e sobre o qual nem sequer há discussão.

Assim sendo, entenderam os ministros - por unanimidade neste ponto - que "um Estado não consagra verdadeiramente a liberdade religiosa sem absoluto respeito aos seus dogmas, suas crenças, liturgias e cultos. O direito fundamental à liberdade religiosa não exige do Estado concordância ou parceria com uma ou várias religiões; exige, tão somente, respeito; impossibilitando-o de mutilar dogmas religiosos de várias crenças" (Voto do ministro Alexandre de Moraes, p. 41).

$\mathrm{Na}$ exposição dos amici curiae ficou claro que o sacrifício de animais nas religiões de matriz africana corresponde a um contato simbólico entre o humano e o divino por meio da morte real de um animal, sendo parte indispensável de sua ritualística mágica, de modo que impedir a sacralização seria uma interferência que descaracterizaria de maneira irreparável seus cultos. Somado a isso, no voto dos ministros ainda se destacam outras religiões - que não de matriz africana, como o judaísmo e o islamismo -, nas quais também tais práticas são parte integrante e essencial de suas liturgias.

Quanto ao uso de crueldade ou maus tratos no processo de sacralização, ficou patente que isso não há, sendo inclusive proibido nas diversas religiões que se valem da prática; entretanto, é impossível assegurar que não haja quem assim o faça (principalmente nos casos de prática de magia do mal, comumente chamada de magia negra), o que, no caso, se encaixaria na vedação constitucional já existente, sendo a única cabível na discussão. Assim, destacou o ministro Alexandre de Moraes em seu voto: 
O candomblé não utiliza mais o termo sacrifício - exatamente para afastar qualquer possibilidade de maus tratos aos animais - mas sim "Sacralização", pois como sacerdotes da religião, especialmente treinados, irão realizar o ato com os rigores e o respeito que o culto exige. As oferendas de alimentos aos Orixás são componentes essenciais dessa religião de matriz africana, inclusive os animais escolhidos para servirem de alimento tem identificação com a própria divindade; por exemplo, para XANGO, o Orixá da Justiça, são destinados galo, carneiro, bode; para IEMANJÁ, mãe de todos os Orixás e Rainha das Águas, são destinados carneiro, pato, galinha e para EXU, Orixá da Ordem e Disciplina, são destinados galos e bode preto (p. 46).

Há todo um ritual e procedimento que devem ser seguidos na sacralização dos animais, com extremo rigor e respeito. Salvo se for criado na casa, o animal deverá chegar, no mínimo, 24 horas antes, onde será realizada a higiene do animal, primeiro com banho de água, depois de água com ervas e incensados; sem qualquer ato de maus tratos, ofensa ou agressão física aos animais, que possa causar sofrimento ou danos. Conforme a crença do Candomblé, o clímax do culto religioso ocorrerá com a realização do contato entre adepto e divindade, por meio do alimento "sangue", considerado a fonte da vida, que irá "regar os objetos sagrados" e os Orixás, sendo misericordiosos, permitem que a carne das oferendas - preparada com azeite de dênde, mel de abelha ou outros ingredientes dependendo da ocasião - seja distribuída aos participantes e mesmo com toda a comunidade, quando os cultos são maiores e em datas festivas. Todos os alimentos são oferecidos acompanhados por cantos especiais.

Desta forma, chega-se à conclusão de que há toda uma liturgia presente, não sendo algo inventado de um dia para o outro, e que, dentro de um contexto de crença até mesmo supera o respeito e significado da vida dos animais, defendida pela linha de pensamento que o deseja proibir.

Dentro do direito comparado, foram citados nos votos vários casos em que a liberdade religiosa foi devidamente respeitada em outros países, como na Alemanha, onde o Tribunal Constitucional considerou o direito de um açougueiro muçulmano de fazer o abate dos animais conforme indica sua religião; na Áustria, onde se considerou que o abate de animais sem anestesia é um costume religioso que deve ser respeitado; na Polônia, onde a liberdade religiosa superou a proibição do abate de animais conforme costumes dos cultos a partir do respeito à garantia da liberdade de religião e o artigo 9 da Convenção Europeia de Direitos do Homem; e na Índia, onde a Suprema Corte recusou-se a banir a prática de sacrifício animal para fins religiosos, com a justificativa de que o assunto é muito sensível e que não se pode fechar os olhos para práticas tradicionais e argumentos de fé que são seguidos há séculos.

\section{OS POSTULADOS NORMATIVOS E O CONFLITO DE REGRAS E PRINCÍPIOS}

Tendo, pois, à frente um aparente conflito entre princípios, há que se buscar na Teoria do Direito o modo de se resolver tal impasse. Dentre os objetivos deste artigo, está o uso da correta nomenclatura e compreensão deste esforço intelectual que ultrapassa a mera técnica e se concretiza num requintado sistema de sopesamento entre os assuntos da mais alta vontade do povo, manifestada nos princípios que lhe são mais caros e indispensáveis para garantia do Estado Democrático de Direito.

Não é difícil se encontrar, tanto na doutrina quanto na jurisprudência, a apresentação deste árduo trabalho como um princípio, o que, ao se fazer, confere-lhe uma força e função no ordenamento jurídico que ele não possui. É comum encontrar-se "princípio da proporcionalidade", "princípio da ponderação", "princípio da razoabilidade" como meios para resolver justamente problemas de conflitos entre princípios, o que já seria difícil de onomasticamente se compreender, quanto mais ainda o será por ver que tais institutos não conduzem à promoção de um fim, nem prescrevem comportamentos (compostos básicos de um princípio), mas apenas indicam modos de raciocínio e de argumentação ligados a normas que indiretamente exigem tais comportamentos.

Neste sentido, segue-se o pensamento de Ávila (2005) e Alexy (2008), que apresentam tais institutos como "postulados" (para o primeiro) ou "máximas" (para o segundo), como forma de sopesamento quando normas de direito fundamental colidirem entre si. Para Ávila $(2005$, p. 88), os postulados "estabelecem a estrutura de aplicação de outras normas, princípios e regras", de modo que, quando não são respeitados, não há violação de postulados, mas, sim, das normas que deixam de ser aplicadas corretamente por falta de utilização adequada dos institutos que garantem sua correta aplicação. 
Os princípios, conforme Alexy, possuem um mandamento de otimização, o que não ocorre no caso da aplicação das máximas, que se apresentam como deveres estruturais que vinculam elementos e ordenam determinada relação entre eles, dando razões substanciais para a aplicação das normas. Esse trabalho, como já citado brevemente, não deve ser chamado de técnica jurídica, uma vez que, na escala de conhecimento, a técnica é um simples aprimoramento do saber-fazer, e, no caso, se está falando de um requintado trabalho científico e filosófico de se sopesar aquilo que de mais importante existe no ordenamento jurídico.

Dito isto, será importante destacar que os postulados normativos ou máximas não se apresentam todos da mesma forma, necessitando de um esmerado trabalho do aplicador na ordenação de vários elementos que, eliminando os conflitos normativos, vão auxiliar na preparação da decisão. Tanto para Ávila (2005) quanto para Alexy (2008), tais postulados (ou máximas) apresentam-se por meio da ponderação, da razoabilidade e da proporcionalidade, cada um com uma exigência e aplicabilidade em casos específicos, e não de maneira geral ou igual, como se pode pensar num olhar menos apurado.

A ponderação trata-se de um método que busca atribuir pesos a elementos coligados sem que haja uma referência específica que indique como será feito este sopesamento, de modo que será indispensável a utilização de alguns critérios sem os quais seria inútil ponderar. Conforme Ávila (2005), independentemente de quais forem os elementos que serão sopesados, será necessário preparar uma intensa estrutura para fazê-lo, ou seja, haverá sempre uma "preparação da ponderação", quando, ao se analisar cuidadosamente todos os elementos e argumentos envolvidos, há que se indicar clara e antecipadamente o que será objeto de sopesamento, a fim de que isso seja parte integrante da decisão posterior. De tudo isso, se procederá o sopesamento mostrando os fundamentos da relação estabelecida entre os elementos (princípios ou regras) e indicando a relação de hierarquia entre eles, de modo que a reconstrução da ponderação tão bem alinhavada deve ser, que poderá ser aplicada, em tese, em outros casos.

Isso, porém, não é o suficiente. Diante da dificuldade do estabelecimento de critérios objetivos para ser feita, a ponderação deve ser acompanhada da concordância prática e da proibição do excesso, como formas de completá-la. No primeiro requisito, tendo em vista se tratar de princípios que não podem simplesmente deixar de existir no ordenamento jurídico, se busca harmonizar - no que for possível - tais valores em conflito; no segundo, tem-se que um princípio constitucional não poderá sofrer uma restrição a ponto de se retirar na totalidade sua eficácia, ou seja, "indica que a aplicação de uma norma, regra ou princípio não pode implicar a impossibilidade de aplicação de uma outra norma, regra ou princípio" (ÁVILA, 2005, p. 97).

A razoabilidade, da mesma forma que os demais postulados, também acaba por ser confundida e apresentada nos tribunais como um princípio, assunto já resolvido anteriormente; entretanto, não bastasse isso, ainda é utilizada muitas vezes como sinônima da proporcionalidade, o que, apesar de não gerar grandes problemas, há que se ter diferenciado para alcançar os fins a que cada uma delas se destina.

Ávila (2005) apresenta a razoabilidade de três formas: como diretriz de relação entre normas gerais com individuais; como vinculação das normas jurídicas com o mundo do qual fazem parte; e como relação de equivalência entre duas grandezas.

No primeiro caso tem-se uma norma geral e não há exceção prevista ao seu cumprimento; no entanto surge um caso posterior que figura como uma exceção, a qual não seria razoável deixar de aceitar; isso aplica-se nos casos em que a exceção não acarretaria grandes problemas ao princípio, ou seja, seria razoável a exceção para não restringir totalmente tal direito. O segundo caso pede que seja razoável exigir-se que haja uma harmonia entre a norma e as condições externas para a sua aplicação, ou seja, também se aplicará a razoabilidade se não se encontrar correlação entre a especificidade exigida pela norma e a nova medida por ela adotada. Por fim, a razoabilidade como equivalência, que se apresenta nos casos em que, mesmo que a norma não traga critérios claros, sempre deverá haver equivalência entre a medida e suas dimensões de alcance.

Por fim, a proporcionalidade, geralmente utilizada nos casos de colisão de princípios, apresentada por Alexy (2008) e dividida em três máximas parciais aplicadas exclusivamente em situações em que há relação de causalidade entre meio (o efeito de uma ação) e fim (a promoção de um estado de coisas), quais sejam: a adequação, a necessidade e a proporcionalidade em sentido estrito, de modo que: um meio será adequado se promover um fim; necessário se, dentre todas as possibilidades igualmente adequadas para se atingir o fim, for o menos restritivo no que concerne aos direitos fundamentais; e proporcional se as vantagens que traz superam as desvantagens que provoca. 
Conforme Ávila (2005), aplicar-se-á a proporcionalidade toda vez que houver uma medida concreta que se destine a realizar um fim, sendo analisadas as possibilidades de a medida realizar a finalidade e ser a menos restritiva acerca dos direitos envolvidos e o fim ser tão relevante que justifique tal restrição.

Em resumo, aplica-se a proporcionalidade quando não se encontra adequação entre o fim desejado e os instrumentos empregados, quando a medida não seja verdadeiramente necessária (havendo outra forma menos gravosa de se alcançar o fim) ou não haja proporcionalidade (em sentido estrito), uma vez que o que se perde com a medida é mais relevante do que aquilo que se ganha.

\section{A APLICAÇ̃̃O DA RAZOABILIDADE À LUZ DO JULGAMENTO DO RE 494.601/RS}

\subsection{Aspectos materiais do RE 494.601/RS}

No ano de 2003 foi promulgada, no Estado do Rio Grande do Sul, uma lei que instituía, no âmbito do Estado, o Código Estadual de Proteção aos Animais (Lei no 11.915/2003 RS), com uma série de regramentos sobre seu tratamento, guarda e abate. Em seu artigo 2ㅇ, constava, in verbis:

Art. 2 - - É vedado:

I - ofender ou agredir fisicamente os animais, sujeitando-os a qualquer tipo de experiência capaz de causar sofrimento ou dano, bem como as que criem condições inaceitáveis de existência;

II - manter animais em local completamente desprovido de asseio ou que lhes impeçam a movimentação, o descanso ou os privem de ar e luminosidade;

III - obrigar animais a trabalhos exorbitantes ou que ultrapassem sua força;

IV - não dar morte rápida e indolor a todo animal cujo extermínio seja necessário para consumo;

$\mathrm{V}$ - exercer a venda ambulante de animais para menores desacompanhados por responsável legal;

$\mathrm{VI}$ - enclausurar animais com outros que os molestem ou aterrorizem;

VII - sacrificar animais com venenos ou outros métodos não preconizados pela Organização Mundial da Saúde - OMS -, nos programas de profilaxia da raiva.

Posteriormente, foi acrescentado ao artigo citado (pela Lei no 12.131/2004 RS) um parágrafo único que trazia que: "Não se enquadra nessa vedação o livre exercício dos cultos e liturgias das religiões de matriz africana", a partir do que houve a impetração de uma Ação Direta de Inconstitucionalidade, cujo julgamento pode ser resumido com base em sua ementa:

TJ/RS - CONSTITUCIONAL. AÇÃO DIRETA. SACRIFÍCIO RITUAL DE ANIMAIS. CONSTITUCIONALIDADE. 1. Não é inconstitucional a Lei 12.131/04-RS, que introduziu parágrafo único ao art. 2. da Lei 11.915/03-RS, explicitando que não infringe ao "Código Estadual de Proteção aos Animais" o sacrifício ritual em cultos e liturgias das religiões de matriz africana, desde que sem excessos ou crueldade. Na verdade, não há norma que proíba a morte de animais, e, de toda sorte, no caso a liberdade de culto permitiria a prática. 2. AÇÃO JULGADA IMPROCEDENTE. VOTOS VENCIDOS.

Tendo em vista o julgamento suprarreferido, o Ministério Público do Rio Grande do Sul ingressou com Recurso Extraordinário apontando a transgressão aos artigos 50, caput, 19, inciso I, e 22, inciso I, da Constituição Federal, indicando que a Lei estadual no 12.131/2004, ao acrescentar o parágrafo único ao artigo 2ㅇda Lei de no 11.915/2003, revelou-se formalmente inconstitucional: 1) por ter versado, indevidamente, matéria penal, de competência privativa da União; 2) porque a Lei dos Crimes Ambientais, de no 9.605/1998, dispõe ser crime maltratar, ferir ou mutilar animais silvestres, domésticos, domesticados, nativos ou exóticos, ou deles abusar; 3) por não estar excepcionado o sacrifício de animais, destinados ou não à alimentação humana, praticado em rituais religiosos, sendo impróprio o Estado do Rio Grande do Sul estabelecer causa de exclusão da ilicitude, sob pena de invadir esfera de competência privativa da União.

No aspecto material, ao privilegiar os cultos de matriz africana, a Lei estadual afrontou o princípio da isonomia, uma vez que também há rituais das religiões judaica e muçulmana envolvendo sacrifício de animais (não contemplados na exceção), e que a supressão do preceito questionado (qual seja, o parágrafo acrescentado) não inviabilizaria a prática de cultos religiosos com matriz africana, estando em jogo o equacionamento entre o direito fundamental à liberdade de consciência e de crença e a proteção aos animais. 
No presente artigo, para se apresentar a razoabilidade utilizada em sede de Corte Constitucional no deslinde do caso, deixar-se-á de lado a parte formal invocada pelo Ministério Público da unidade, valendo-se apenas da análise da parte material das alegações.

Assim, tendo em mãos o deslinde do caso, já se sabe da negativa de provimento do recurso, que se deu por unanimidade; não houve discordâncias quanto à exigência do respeito ao preceito constante no artigo 225, §1으, inciso VII c/c §7으 da Constituição Federal acerca da proibição da crueldade para com os animais, independentemente do fim (alimentar, cultural, esportivo ou religioso), seguindo jurisprudência do próprio Supremo Tribunal Federal já manifestada no RE 153.531, ao afirmar que "a obrigação constitucional do Estado de assegurar a todos os cidadãos o pleno exercício de direitos culturais, promovendo a apreciação e difusão de manifestações culturais, não exime o Estado de observar o dispositivo constitucional que proíbe o tratamento cruel de animais" (RE 153.531, rel. min. Marco Aurélio, Segundo Turma, DJ 13.03.1998).

No mesmo sentido, também já foi julgada pelo STF a questão da crueldade na prática cultural da "Farra do Boi", quando ficou patente que deve o legislador infraconstitucional legislar para que - se mantida - aconteça sem submeter os animais à crueldade; ainda destaca-se o caso da ADI 1.856, rel. min. Celso de Mello, DJe 13.10.2011, que julgou inconstitucional a Lei do Estado do Rio de Janeiro que regulamentava a prática da rinha de galos que, "além de caracterizar prática criminosa tipificada na legislação ambiental, configura conduta atentatória à Constituição da República, que veda a submissão de animas a atos de crueldade".

Percebe-se que, em todos os casos, não há acolhimento do preceito constitucional do artigo 225 , §10, inciso VII, como restritivo ao abate de animais (independentemente do fim), mas, sim, à sua não submissão à crueldade, casos em que, havendo dúvidas, laudos técnicos podem ser solicitados para que isso seja aferido, como no caso da ADI 4.983, rel. min. Marco Aurélio, DJe 26.04.2017, que tratou da prática da vaquejada constatando que a crueldade existia, o que, no caso em pauta, justamente mostrou-se ao contrário, ao se tratar do modo como são feitas as imolações nos cultos religiosos que exigem tal prática:

Ao contrário do abate comercial, o abate religioso praticado por judeus, muçulmanos ou fiéis das Religiões Afrobrasileiras utiliza um método que acarreta morte instantânea e com o mínimo de dor - a degola. Trata-se, aliás, de exigência prevista na Declaração Universal dos Direitos dos Animais: "Se for necessário matar um animal, ele deve ser morto instantaneamente, sem dor e de modo a não provocar-lhe angústia" (Declaração Universal dos Direitos dos Animais, proclamada pela Unesco em 27 de janeiro de 1978, art. 3o, item 2) - (Voto do Ministro Edson Fachin, p. 26, ao apresentar argumentação da União das Tendas de Umbanda e Candomblé do Brasil)

Da mesma forma, destacava ainda o ministro que o próprio Ministério da Agricultura, Pecuária e Abastecimento disciplinou, na Instrução Normativa n. 3/2000, o regulamento técnico de métodos de insensibilização para o abate humanitário de animais de açougue, quando, em seu artigo 11.3, expressamente prevê que "é facultado o sacrifício de animais de acordo com preceitos religiosos, desde que sejam destinados ao consumo por comunidade religiosa que os requeria ou ao comércio internacional com países que façam essa exigência, sempre atendidos os métodos de contenção dos animais".

Ou seja, apresenta-se forçosa a interpretação de que o artigo 225 já citado venha de qualquer forma a proibir ou desincentivar o abate de animais, posto que "é necessário harmonizar a proteção da fauna com o fato de o homem ser carnívoro. Revela-se desproporcional impedir todo e qualquer sacrifício religioso de animais, aniquilando o exercício do direito à liberdade de crença de determinados grupos, quando diariamente a população consome carnes de várias espécies. Existem situações nas quais o abate surge constitucionalmente admissível, como no estado de necessidade - para a autodefesa - ou para fins de alimentação" (Voto do ministro Marco Aurélio, p. 15).

\subsection{A aplicação do postulado da razoabilidade}

Como já tratado no item 3 deste artigo, os postulados normativos ou máximas vêm em socorro do julgador, oferecendo-lhe métodos eficazes para a condução a um correto julgamento, exigindo do aplicador um esmerado trabalho para que se alcance o fim esperado. Não raras vezes, entretanto, os postulados são confundidos, misturando-se os métodos e correndo-se o risco de não se alcançar o que se quer. 
Quando ainda em vistas de ser julgado o RE, os clamores dos defensores dos direitos dos animais pediam atenção à "importância da interpretação hermenêutica e o princípio da proporcionalidade dos direitos fundamentais, a fim de perceber que o direito à vida, humana e não humana, sobrepõe-se ao direito à liberdade religiosa" (BRAZ et al., 2019, p. 16).

Seguindo esta linha de pensamento, estariam contrapostos dois direitos fundamentais, aplicando-se, então, a proporcionalidade, com suas três máximas parciais já citadas, quais sejam, da adequação, da necessidade e da proporcionalidade (em sentido estrito). Recorda-se que um meio será considerado adequado se promove um fim; será necessário se, dentre todos os meios igualmente adequados para alcançar o fim, for o menos restritivo relativamente aos direitos fundamentais, e proporcional (em sentido estrito) se as vantagens que promove superam as desvantagens que provoca (ÁVILA, 2005).

Percebe-se, todavia, neste caso, que não há como se aplicar a máxima da proporcionalidade, tendo em vista que, primeiramente, não há conflito entre os princípios do direito à vida e do direito à liberdade de culto, pois não há indicação de preceito constitucional que traga a proibição da morte de animais, senão apenas o uso de crueldade para com eles, seja no trato, seja no abate. Engana-se o leitor, à primeira vista, ao pensar que a ação cuida disso, posto que não há tal princípio com o qual se confrontar.

Mesmo que houvesse, ficaria ainda prejudicada a proporcionalidade, pois, seguindo suas três máximas parciais, o meio é adequado, mas não necessário, considerando que, caso houvesse a proibição da prática do sacrifício, as religiões que dele fazem uso ficariam irremediavelmente prejudicadas; por fim, não haveria proporcionalidade em sentido estrito, pois não haveria vantagem em proibir o abate em cultos, e eles continuariam a acontecer em escala insuperavelmente maior para o consumo humano.

Seguindo o mesmo raciocínio, conforme os critérios inerentes aos postulados normativos, não seria possível a ponderação de bens jurídicos no caso em pauta, pois, como já visto, para a aplicação da ponderação é necessária uma preparação na qual se determine com clareza aquilo que será sopesado, sendo possível indicar, na sequência, a primazia entre os princípios ponderados, o que não há. Além disso, a ponderação vem acompanhada da concordância prática e da proibição do excesso, quando, na primeira, busca-se a harmonia necessária entre valores, parcial ou totalmente contrários, procurando encontrar uma otimização entre eles e a proibição do excesso, indicando que uma regra ou princípio constitucional não pode ser restringido a ponto de não lhe deixar um mínimo de eficácia.

No caso, nenhuma das três exigências da ponderação consegue ser cumprida, pois não há colisão de princípios em jogo, posto que há a proteção do princípio da liberdade de culto, mas não há a vedação do sacrifício de animais, o que prejudica também a concordância prática, uma vez que não há o que se harmonizar; o que restaria aqui seria a proibição do excesso, quando a crueldade deveria ser proibida, o que, todavia, não está em discussão, pois as religiões que se valem da prática dos sacrifícios já vedam o procedimento, além de exigir, ainda, outras condutas de respeito e preparação ao animal que será sacralizado. Poderia haver, sim apenas a título de exemplo -, a ponderação justamente em caso contrário, ou seja, se não tivesse havido a inclusão do parágrafo que autorizasse, como exceção à regra geral, o sacrifício de animais em cultos religiosos, pois seria um excesso a ser ponderado e um restritivo de princípio constitucional, mas não é do que se trata nem foi o que aconteceu.

Resta, então, a análise da razoabilidade que se apresenta como postulado mais acertado e utilizado no julgamento em questão. Recorde-se que, conforme Ávila (2005), a razoabilidade exige a harmonização entre a norma geral e o caso individual, ou seja, tem-se uma norma geral e não há exceção prevista relativa ao seu cumprimento; entretanto, um caso posterior, mesmo não previsto, faz com que caiba uma exceção, levando em conta a razoabilidade do caso, ou melhor, quando não seria razoável não se aceitar tal exceção.

Sendo assim, pronunciou-se a Procuradoria Geral da República no sentido de que, se separando a restrição ao exercício do direito à liberdade de culto com a prevalência do interesse ambiental confrontado, inexistirá razoabilidade na mútua relação meio-fim: "à anulação do primeiro não corresponderá nenhum ganho qualitativo do segundo. A par das imolações rituais, seguirão os abates de forma extensiva dos mesmos animais, já agora como fonte de proteína na cadeia alimentar humana. Não há como pressupor tenha o sacrifício religioso requintes de crueldade e que seja obsequiosa a extensiva matança comercial" (BRASIL, 2019, p. 8-9). 
Procedeu, assim, caso em pauta: a exceção trazida com o acréscimo do parágrafo em questão apresenta-se razoável justamente em respeito ao princípio constitucional da liberdade de culto, não havendo inconstitucionalidade ao acrescentá-lo, mas justamente o contrário. Desta forma, e seguindo esta esteira de pensamento e método, desta forma ficou decidido:

O sacrifício de animais é aceitável se, afastados os maus-tratos no abate, a carne for direcionada ao consumo humano. Com isso, mantém-se o nível de proteção conferido aos animais pela Constituição Federal sem a integral supressão do exercício da liberdade religiosa (Voto do Ministro Marco Aurélio).

Ante, de um lado, as incertezas acerca do alcance do sofrimento animal, e, de outro, a dimensão plural que se deve reconhecer às manifestações culturais, é evidente que a proibição do sacrifício acabaria por negar a própria essência da pluralidade, impondo determinada visão de mundo a uma cultura que está a merecer, como já dito, especial proteção constitucional. Se é certo que a interpretação constitucional aqui fixada estende-se às demais religiões que também adotem práticas sacrificiais, não ofende a igualdade, ao contrário, vai a seu encontro, a designação de especial proteção a religiões de culturas que, historicamente, foram estigmatizadas. Não há, portanto, qualquer vício material na norma impugnada na ação direta, cujo recurso extraordinário ora se examina (Voto do Ministro Edson Fachin).

Não é inconstitucional, portanto, a Lei no 12.131 que introduziu parágrafo único ao art. 20 da Lei no 11.915, explicitando que não infringe o Código Estadual de Proteção aos Animais o sacrifício ritual em cultos de liturgias das religiões de matriz africana, desde que sem excessos ou crueldades. Na verdade, não há norma que proíba a morte de animais (Voto do Ministro Alexandre de Moraes).

Portanto, Presidente, enfatizando uma vez mais que considero que a ética animal também é um avanço civilizatório no mundo contemporâneo, endossada pelo Supremo Tribunal Federal em diversos precedentes, que interditaram manifestações culturais que envolviam crueldade contra os animais, creio que a diferenciação aqui é evidente, não apenas porque não se trata de sacrifício ou de sacralização para fins de entretenimento, mas, sim, para fins de exercício de um direito fundamental, que é a liberdade religiosa, como também porque, pelo que pude apreender, não existe tratamento cruel desses animais. Pelo contrário, a sacralização deve ser conduzida sem o sofrimento inútil do animal (Voto do Ministro Roberto Barroso).

Este abate religioso é um abate que se fundamenta na fé e na espiritualidade. E, por incrível que pareça, $90 \%$ da população brasileira realiza o abate comercial e somente $4 \%$ dos brasileiros é que realizam esse abate religioso; considerando que, nesse senso que chegou a esse percentual, nós encontramos um abate realizado às vésperas do Dia do Perdão, do Yom Kipur: 110.000 judeus; o abate que é realizado pela comunidade muçulmana: 35.000 muçulmanos; e 700.000 fiéis de Candomblé e da Umbanda (Voto do Ministro Luiz Fux).

Fica claro, então, que, tendo em vista a razoabilidade necessária para o caso, decidiram os ministros que acertou o Poder Executivo Estadual em acrescentar exceção à regra geral, não se tratando de conflito de princípios, mas da aceitabilidade da exceção à regra geral, uma vez que, não sendo razoável tal restrição, que embora não invalidasse no todo o culto das religiões envolvidas, as atingiria na essência, ferindo-as na liturgia, na tradição e sem escopo constitucional para fazê-lo.

\section{CONCLUSÃO}

Ante todo o exposto, percebe-se, não apenas na população em geral, mas também entre os próprios integrantes dos órgãos jurisdicionais, apesar de mais de 30 anos da promulgação do texto constitucional vigente, um grande desconhecimento sobre seus princípios e uma grande falta de precisão terminológica e metodológica para sua compreensão e aplicação normativa. Isto, somado aos lobbys, pode gerar muita insegurança jurídica, sendo papel não apenas dos órgãos jurisdicionais, mas igualmente dos juristas em geral, cuidar para que não se consiga eventual alteração essencial à força, mas que seja sempre fruto de um debate maduro que colabore na consolidação da democracia almejada.

Neste sentido, este artigo buscou colaborar na precisão conceitual da liberdade religiosa e seus desdobramentos na liberdade de crença e culto, mostrando aquilo que poderia vir como limitador de tal princípio e, ao mesmo tempo, do outro lado, até onde ele pode ir sem que fira outras questões essenciais e necessárias ao tempero democrático. 
Ao se debruçar sobre os postulados normativos, retira-se deles o caráter principiológico, enquadrando-os como métodos que são, mostrando o esforço científico e filosófico que deve haver para utilizá-los corretamente e compreendendo-os para que venham a colaborar e garantir os princípios e regras a que dão suporte na aplicação, e distinguindo aquilo que é ponderável, razoável e proporcional a partir da casuística da Corte Superior ao tratar dos princípios que lhe são mais caros, avançando, de modo cuidadoso, mas destemido, na consolidação da democracia almejada.

\section{REFERÊNCIAS}

ALVES, Fernando de Brito; RIGÃO, Livia Carla Silva. Cultura da periferia e as canções de rap: um olhar para as "vozes silenciadas" a partir da filosofia de Enrique Dussel. Revista Direitos Sociais e Políticas Públicas - Unifafibe, v. 8, n. 1, 2020.

ALEXY, Robert. Teoria dos direitos fundamentais. São Paulo: Malheiros, 2008.

ÁVILA, Humberto. Teoria dos princípios, da definição à aplicação dos princípios jurídicos. 4. ed. São Paulo: Malheiros, 2005. BASTOS, Celso Ribeiro. Curso de Direito Constitucional. 14. ed. São Paulo: Saraiva, 1992.

BARROSO, Luís Roberto. Interpretação e aplicação da Constituição. 4. ed. Rio de Janeiro: Renovar, 2001.

BRAZ, Laura Cecília Fagundes et al. Sacrifício de animais em e cerimônias religiosas na pauta do STF: Direito à liberdade religiosa sobreposto ao direito à vida animal não humana. Revista Eletrônica do Curso de Direito da UFSM, v. 14, n. 3, e32093, set./ dez. 2019.

BRASIL. Constituição Federal. Brasília: Senado Federal, 1988. Disponível em: http://www.planalto.gov.br/ccivil_03/constituicao/constituicaocompilado.htm. Acesso em: 20 ago. 2020.

BRASIL. Lei no 11.915 de 21 de maio de 2003. Institui o Código Estadual de Proteção aos Animais, no âmbito do Estado do Rio Grande do Sul. In: Diário Oficial Estadual, Rio Grande do Sul, RS, 22 maio 2003. Disponível em: http://Iproweb.procempa.com. br/pmpa/prefpoa/seda/usu_doc/lei_estadual_11.915.pdf. Acesso em: 20 ago. 2020.

BRASIL. Lei no 12.131 de 22 de julho de 2004. Acrescenta parágrafo único ao artigo 2ㅇ da Lei no 11.915, de 21 de maio de 2003, que institui o Código Estadual de Proteção aos Animais, no âmbito do Estado do Rio Grande do Sul. In: Diário Oficial Estadual, Rio Grande do Sul, RS, 23 jul. 2004. Disponível em: http://www.al.rs.gov.br/filerepository/repLegis/arquivos/12.131.pdf. Acesso em: 20 ago. 2020.

BRASIL. Supremo Tribunal Federal. Inteiro teor do Acórdão de decisão que negou provimento ao Recurso Extraordinário 494.601 Rio Grande do Sul. Relator: ministro Marco Aurélio. 28 mar. 2019. Disponível em: http://portal.stf.jus.br/processos/ downloadPeca.asp?id=15341718509\&ext=.pdf. Acesso em: 20 ago. 2020.

CASTRO, Alexander; NASCIMENTO, Gabriel Bassaga. Liberdade de expressão frente à liberdade religiosa: direitos fundamentais em conflito e proteção de direitos da personalidade frente a discursos de ódio. Revista Direitos Sociais e Políticas Públicas Unifafibe, v. 7, n. 3, 2019.

COSTA, Fabrício Veiga; PINTO, Alisson Alves. A ressocialização do detento a partir do prazo para o cumprimento da função social da empresa na sociedade contemporânea. Revista Direitos Sociais e Políticas Públicas - Unifafibe, v. 7, n. 3, 2019.

CRETELLA JÚNIOR, José. Comentários à constituição Brasileira de 1988: v. 1. Art. 1o a 5ㅇ, incs. I a LXVII. Rio de Janeiro: Forense Universitária, 1997.

DWORKIN, Ronald. O império do direito. São Paulo: Martins Fontes, 1999.

LAZCANO, Alfonso Jaime Martínez. El derecho convencional y los retos de su implementación en los estados parte. Revista Direitos Sociais e Políticas Públicas - Unifafibe, v. 7, n. 3, 2019.

LEVAI, Laerte Fernando. Crueldade consentida: crítica à razão antropocêntrica. Revista Brasileira de Direito Animal, v. 1, n. 1, jan./dez. 2006. Salvador: Instituto de Abolicionismo Animal, 2006.

LOURENÇO, Daniel Braga. A liberdade de culto e o direito dos animais (parte 2). Revista Brasileira de Direito Animal, Salvador: Instituto do Abolicionismo Animal, v. 2, n. 3, 2007.

LOZANO, Luis Gerardo Rodrígues. León duguit y el servicio público: ideas para el siglo XXI. Revista Direitos Sociais e Políticas Públicas - Unifafibe, v. 8, n. 1, 2020.

LUCAS, Doglas Cesar. Direitos humanos, identidade e a política de reconhecimento de Charles Taylor. Revista Direitos Sociais e Políticas Públicas - Unifafibe, v. 7, n. 3, 2019.

MAGLIACANE, Alessia. L'armee des reserves dans la mondialisation: la parabole de la femme italienne de la constitution au post-fordisme. Revista Direitos Sociais e Políticas Públicas - Unifafibe, v. 7, n. 3, 2019.

MARTíN, Ignacio Durbán Origen y fundamentos del sistema plurilegislativo civil español. Revista Direitos Sociais e Políticas Públicas - Unifafibe, v. 8, n. 1, 2020.

MORAES, Alexandre de. Direitos humanos fundamentais: teoria geral, comentários aos arts. 1ㅇ a 5 da Constituição da República Federativa do Brasil, doutrina e jurisprudência. 9. ed. São Paulo: Atlas, 2011. 
MORAES, Maria Valentina de; LEAL, Mônia Clarissa Hennig. Supremo Tribunal Federal e diálogo institucional: há um controle jurisdicional de políticas públicas no Brasil? Revista Direitos Sociais e Políticas Públicas - Unifafibe, v. 7, n. 3, 2019.

SILVA, Tagore Trajano de Almeida. Direito animal e os paradigmas de Thomas Kuhn: reforma ou revolução científica na teoria do direito? Revista Brasileira de Direito Animal, Salvador: Instituto do Abolicionismo Animal, v. 2, n. 3, jul./dez. 2007. 